\title{
Impact of chronic unpredicted mild stress-induced depression on repaglinide fate via glucocorticoid signaling pathway
}

\author{
Hongyan Wei ${ }^{1,2, *}$, Ting Zhou ${ }^{1, *}$, Boyu Tan ${ }^{2}$, Lei Zhang ${ }^{3}$, Mingming Li $^{1}$, Zhijun Xiao ${ }^{1}$ \\ and Feng $X \mathbf{u}^{1,3}$ \\ ${ }^{1}$ Fengxian Hospital, Southern Medical University, Shanghai, China \\ ${ }^{2}$ Hunan Provincial People's Hospital, Hunan Normal University, Changsha, China \\ 3 Joint Research Center for Translation Medicine, East China Normal University, Shanghai, China \\ *These authors have contributed equally to this work
}

Correspondence to: Feng Xu, email: andrewfxu1998@gmail.com

Keywords: chronic unpredicted mild stress(CUMS), depression, repaglinide, drug-metabolizing enzymes (DMEs), glucocorticoid and adrenergic signaling pathway

Received: March 29, $2017 \quad$ Accepted: April 24, $2017 \quad$ Published: May 15, 2017

Copyright: Wei et al. This is an open-access article distributed under the terms of the Creative Commons Attribution License 3.0 (CC BY 3.0 ), which permits unrestricted use, distribution, and reproduction in any medium, provided the original author and source are credited.

\section{ABSTRACT}

Chronic unpredicted mild stress (CUMS)-induced depression could alter the pharmacokinetics of many drugs in rats, however, the underlying mechanism is not clear. In this work we studied the pharmacokinetics of repaglinide, and explored the role of glucocorticoid and adrenergic signaling pathway in regulating drug metabolizing enzymes (DMEs) in GK rats and BRL 3A cells. The plasma cortisol and epinephrine levels were increased, meanwhile the pharmacokinetics of repaglinide were altered significantly in depression model rats. Forty-nine genes in liver of model rats displayed significant difference comparing to control rats. The differentially expressed genes enriched in the drug metabolism and steroid hormone biosynthesis pathway significantly, and Nr1i3 matched 335 connectivity genes. CAR and Ugt1a1 protein expression were enhanced significantly in liver of model rats. The mRNA expression of Ugt1a1 and $\mathrm{Nr1i2}$ were increased 2 and 4 times respectively with dexamethasone (DEX) and 8-Br-cAMP co-treatment in BRL 3A cells. The protein expression of PXR was up-regulated, too. However, RU486 reversed the up-regulated effect. The adrenergic receptor agonists had little impact on the DMEs in BRL 3A. Our data suggested that CUMS-induced depression might up-regulate DMEs expression via glucocorticoid signaling pathway, and accelerate the fate of the repaglinide in spontaneous diabetes rats.

\section{INTRODUCTION}

Stress is a constant factor in modern life and has become one of the most important problems affecting human health in our society [1-4]. Long-term stress may disturb the homeostasis, and lead to psychological diseases such as major depressive disorder [5-7]. The hypothalamic-pituitary-adrenal (HPA) axis with the endpoint release of corticosterone into the circulation plays a role in mediating the neuroendocrine response to stress [8]. Once given with depressive stress, concentrations of corticotropin-releasing hormone $(\mathrm{CRH})$ are usually elevated, and then declined with the administration of antidepressants [9]. Evidence showed that maternal deprivation stress may modify the expression of many cytochrome P-450 (CYP450) genes, thus affecting the efficacy and toxicity of relevant drugs [10]. The impact of stress on drug metabolism is stress-specific, isozymespecific, gender-specific, and species-specific [11].

Currently more documents demonstrated that comorbidity with depression in diabetes might influence hypoglycemic agent efficacy in diabetic patients [12]. Repaglinide, a new prandial glucose regulator, is metabolized dominantly by $\mathrm{CYP} 2 \mathrm{C} 8$ and partially by CYP3A4 in human beings [13]. If CYP2C8 is inhibited due to various reasons, it will be replaced by CYP3A4 [14]. CYP3A4 is regulated by many transcription factors, among which the pregnane $\mathrm{X}$ 
receptor/steroid and xenobiotic receptor $(\mathrm{PXR} / \mathrm{SXR}$, Nr1i2) have been identified as the most critical. The genetic polymorphism of PXR had impact on the pharmacokinetics and pharmacodynamics of repaglinide in healthy Chinese volunteers, and showed that subjects with genotype of $-298 \mathrm{G} / \mathrm{G}$ and $11193 \mathrm{C} / \mathrm{C}$ in PXR have a decreased elimination rate of CYP3A4/2C8 [15]. Our previous work found that chronic unpredicted mild stress (CUMS)-induced depression could alter the pharmacokinetics of many drugs in rats [16-19]. However, the molecular mechanisms underlying the stress and drug metabolism change are not fully understood. We herein explored the pharmacokinetics of repaglinide in depression model rats first, and then focused on the role of glucocorticoid and adrenergic signaling pathway in regulating drug-metabolizing enzymes (DMEs) expression in model rats.

\section{RESULTS}

\section{Establishment of CUMS-induced depression in GK rats}

As shown in Figure 1, no significant differences were found between the two groups prior to model establishment. However, after 8 weeks' stress, the rats in the CUMS depression group displayed depressivelike behaviors. Open-field test showed that the vertical and horizontal scores in the CUMS depression group significantly decreased from $50.83 \pm 8.04$ to $32.08 \pm 8.36$ $(p<0.01)$ and $121.75 \pm 8.82$ to $79.08 \pm 10.55(p<0.01)$, respectively. The sucrose preference values in the CUMS depression group significantly decreased from $71.63 \pm 11.08$ to $55.53 \pm 9.55(p<0.01)$. At the same time the plasma cortisol (CORT) and epinephrine (NE) concentration in CUMS depression group were significantly increased about $30 \%$ (240.83 \pm 87.49 to $322.67 \pm 84.11, p<0.05)$ and $45 \%(411.14 \pm 61.31$ to $609.75 \pm 71.21, p<0.05)$, respectively. No change was existed within control group. These results confirmed CUMS-induced depression rat model was established successfully.

\section{Pharmacokinetics disturbance of repaglinide in GK depression model rats}

CUMS-induced depression on repaglinide pharmacokinetics in rats were presents in Figure 2 and Table 1. CUMS-induced depression accelerated the fate of repaglinde: speeding $\mathrm{T}_{1 / 2}$ by $17.4 \%$ (from $2.53 \pm 0.33 \mathrm{~h}$ to $2.09 \pm 0.46, p<0.05$ ), $\mathrm{T}_{\max }$ by $26.8 \%$ ( from $0.71 \pm 0.10 \mathrm{~h}$ to $0.52 \pm 0.07 \mathrm{~h}, p<0.05)$, and decreasing $\mathrm{C}_{\max }$ by $10.7 \%$ (from $2263.46 \pm 187.18 \mathrm{ng} / \mathrm{ml}$ to $2020.56 \pm 208.31 \mathrm{ng} / \mathrm{ml}$, $p<0.05$ ), $\mathrm{AUC}_{0-\infty}$ by $22.3 \%$ (from $6685.46 \pm 983.24 \mathrm{ng}$ / $\mathrm{ml} \cdot \mathrm{h}$ to $5194.02 \pm 801.19 \mathrm{ng} / \mathrm{ml} \cdot \mathrm{h}, p<0.05)$ and $\mathrm{MRT}_{0-\infty}$ by $18 \%$ (from $3.00 \pm 0.17 \mathrm{~h}$ to $2.46 \pm 0.12 \mathrm{~h}, p<0.05$ ).

\section{Analysis and confirmation of differentially expressed genes in liver tissue of GK rats}

To show mRNA expression profile in CUMSinduced depression GK rats, we used a stringency cutoff to identify significantly differently mRNAs $(P<0.05$, Fold Change $\geq 1.5$ or $\leq 0.5$ ) and two-dimensional hierarchical clustering 3.0 to represent expression profiles between samples. The GeneChip results illustrated that a greater number of differentially expressed probes were observed between the two groups, which matched 49 differentially expressed genes (DEGs). Among them, 13 DEGs were down-regulated, and 36 were up-regulated in depression rats (Figure 3A). The hierarchical clustering of DEGs was visualized as a heatmap (Figure 4). Based on the GeneSpring software analysis the up-regulated DEGs were interconnected and formed gene expression networks. Nrli3 matched 335 connectivity, which regulated the Ugtla1, Ugt2b1, Cyp3a18 and others genes expression and function (Figure 5 and Table 2).

To determine which pathway might be involved in CUMS-induced depression, KEGG pathway analysis was used to authenticate pathways and understand biological functions of significantly differentially expressed genes. The result indicated that the up-regulated DEGs were enriched in 10 pathways, including the drug metabolism, steroid hormone biosynthesis, and so on (Figure 3C and Table 3). Steroid hormone biosynthesis (rno00140, FDR $=0.007$ ) and Drug metabolism (rno00982, FDR $=0.058)$ were significantly enriched pathways. Five genes, namely Cyp3a18, Ugtla1, Ugt2b1,Cyp $2 b 1 / 2$ and Gsta5, were included in drug-metabolism pathway. Additionally, Cyp17al instead of Gsta5, and other four genes, were also enriched in steroid hormone biosynthesis pathway.

These DEGs relevant to drug-metabolism and steroid hormone biosynthesis in the liver tissue of GK rats were validated by quantitative real-time polymerase chain reaction (qRT-PCR). The result showed that Cyp17a1, Cyp3a18, Cyp2b1/2, Ugt1a1, Ugt2b1, Gsta5, and Nr1i3 were increased approximately $2-4$ folds in liver tissue of model rats compared with control rats (Figure 3B). The relative foldchanges detected by qRT-PCR were consistent with the microarray results, indicating the dependability of our microarray platform.

\section{Effect of glucocorticoids and adrenergic pathway on drug metabolizing-related genes expression in BRL 3A cells}

CCK assay showed that DEX, DEXT, PE, ISO of $1 \mu \mathrm{mol} / \mathrm{L}$ does not affect BRL $3 \mathrm{~A}$ cell viability. DEX of $1 \mu \mathrm{mol} / \mathrm{L}$ was set as combination concentration as cotreated with 8-Br-cAMP or RU486, respectively in the following study (Figure 6).

In vitro cell test displayed that the mRNA expression of Ugt1al and Cyp3a18 were enhanced significantly with 
Table 1: The main pharmacokinetic parameters of repaglinide in plasma of GK rats

\begin{tabular}{lll}
\hline Parameters & CUMS group & Control group \\
\hline $\mathrm{T}_{1 / 2}(\mathrm{~h})$ & $2.09 \pm 0.46^{*}$ & $2.53 \pm 0.33$ \\
$\mathrm{~T}_{\text {max }}(\mathrm{h})$ & $0.52 \pm 0.07^{*}$ & $0.71 \pm 0.10$ \\
$\mathrm{C}_{\max }(\mathrm{ng} / \mathrm{mL})$ & $2020.56 \pm 208.31^{*}$ & $2263.46 \pm 187.18$ \\
$\mathrm{AUC}_{0-\infty}(\mathrm{ng} / \mathrm{mL} \cdot \mathrm{h})$ & $5194.02 \pm 801.19^{*}$ & $6685.46 \pm 983.24$ \\
$\mathrm{MRT}_{0-\infty}(\mathrm{h})$ & $2.46 \pm 0.12^{*}$ & $3.00 \pm 0.17$ \\
\hline
\end{tabular}

${ }^{*} p<0.05$, compared with control group $(n=10$, mean $\pm \mathrm{SD})$.
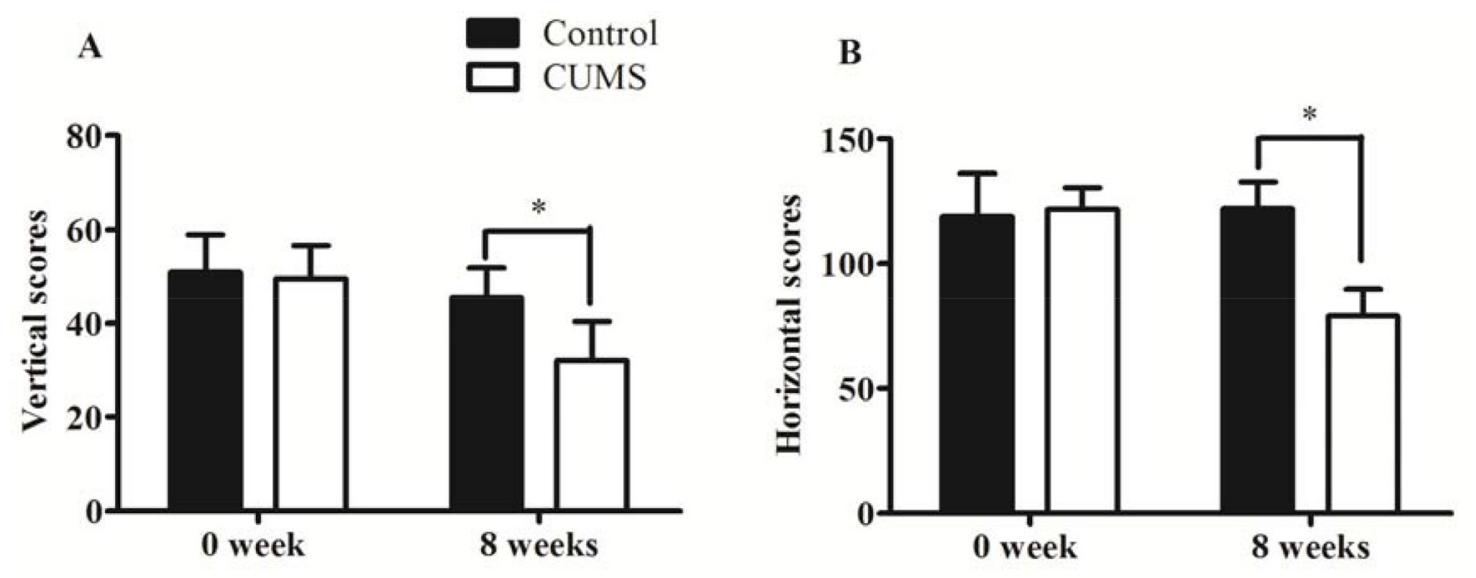

C

D
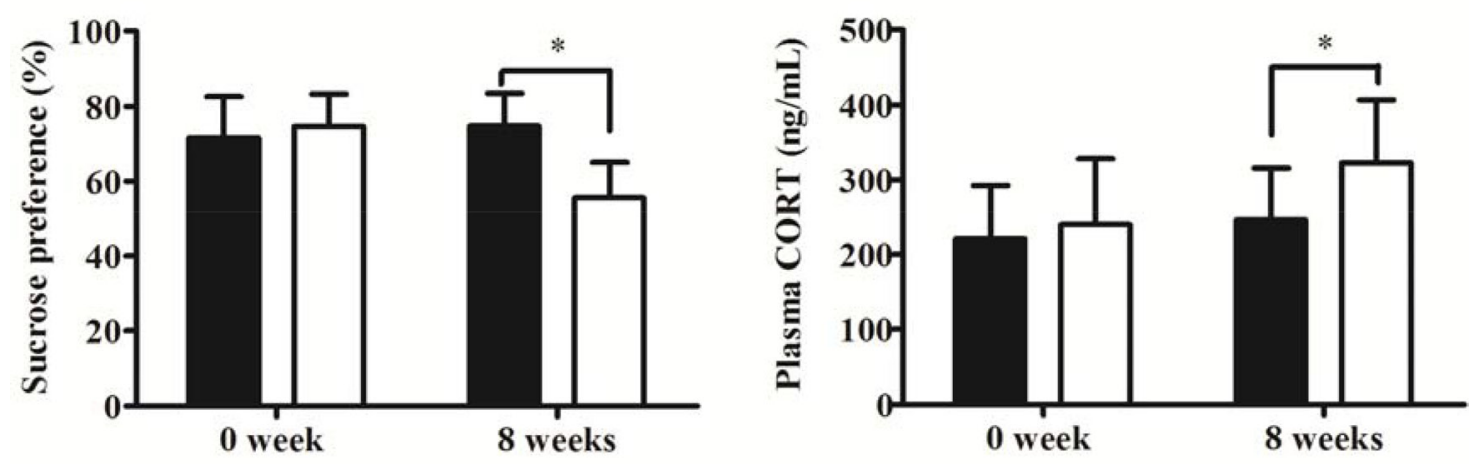

$\mathbf{E}$

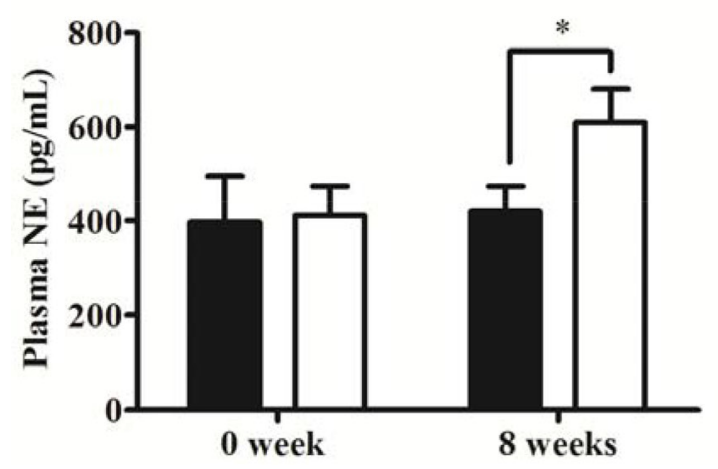

Figure 1: Validation of CUMS-induced depression model in GK rats. (A) Vertical scores; (B) Horizontal scores; (C) Sucrose Preference Tests; (D) Plasma CORT concentration; (E) Plasma NE concentration. The data are presented as mean $\pm \operatorname{SD}(n=10) .{ }^{*} p<0.05$, compared with control group. 
Table 2: The network of the up-regulated differentially expressed genes

\begin{tabular}{|c|c|c|c|c|c|}
\hline Probe Set ID & Gene Symbol & Gene Title & $P$ Value & $\begin{array}{c}\text { Fold } \\
\text { Change }\end{array}$ & $\begin{array}{c}\text { Global } \\
\text { Connectivity }\end{array}$ \\
\hline 1395976_at & Plekha8 & $\begin{array}{l}\text { pleckstrin homology domain } \\
\text { containing, family A (phosphoinositide } \\
\text { binding specific) member } 8\end{array}$ & 0.043 & 1.524 & 1 \\
\hline 1387924_at & Ngef & $\begin{array}{l}\text { ephexin-1-like///neuronal guanine } \\
\text { nucleotide exchange factor }\end{array}$ & 0.047 & 1.76 & 4 \\
\hline 1370592_at & Kegl & kidney expressed gene 1 & 0.036 & 1.77 & 4 \\
\hline 1389253_at & Vnn1 & vanin 1 & 0.030 & 2.00 & 6 \\
\hline 1368068_a_at & Pacsin 2 & $\begin{array}{l}\text { protein kinase } \mathrm{C} \text { and casein kinase } \\
\text { substrate in neurons } 2\end{array}$ & 0.046 & 1.56 & 6 \\
\hline 1368475 at & Colq & $\begin{array}{l}\text { collagen-like tail subunit (single } \\
\text { strand of homotrimer) of asymmetric } \\
\text { acetylcholinesterase }\end{array}$ & 0.047 & 1.85 & 12 \\
\hline 1381958_at & Topbpl & $\begin{array}{l}\text { topoisomerase (DNA) II binding } \\
\text { protein } 1\end{array}$ & 0.005 & 1.62 & 15 \\
\hline 1398307_at & Сур3а18 & $\begin{array}{l}\text { cytochrome } \mathrm{P} 450 \text {, family } 3 \text {, subfamily } \\
\text { a, polypeptide } 18\end{array}$ & 0.028 & 1.50 & 16 \\
\hline 1367659_s_at & Ecil & enoyl-CoA delta isomerase 1 & 0.033 & 1.64 & 19 \\
\hline 1370613_s_at & Ugtlas & $\begin{array}{l}\text { UDP glucuronosyltransferase } 1 \text { family, } \\
\text { polypeptide A } 8\end{array}$ & 0.004 & 1.51 & 19 \\
\hline 1387936_at & Sult2a2 & $\begin{array}{l}\text { sulfotransferase family } 2 \mathrm{~A} \text {, } \\
\text { dehydroepiandrosterone (DHEA)- } \\
\text { preferring, member } 2\end{array}$ & 0.003 & 2.74 & 20 \\
\hline 1370613_s_at & $U g t 1 a 7 c$ & $\begin{array}{l}\text { UDP glucuronosyltransferase } 1 \text { family, } \\
\text { polypeptide A7C }\end{array}$ & 0.004 & 1.51 & 20 \\
\hline 1371089_at & Gsta5 & glutathione S-transferase Yc2 subunit & 0.028 & 2.77 & 43 \\
\hline 1387123_at & Cyp17a1 & $\begin{array}{l}\text { cytochrome } \mathrm{P} 450 \text {, family } 17 \text {, subfamily } \\
\text { a, polypeptide } 1\end{array}$ & 0.032 & 2.90 & 49 \\
\hline 1368283_at & Ehhadh & $\begin{array}{l}\text { enoyl-CoA, hydratase/3-hydroxyacyl } \\
\text { CoA dehydrogenase }\end{array}$ & 0.008 & 1.58 & 69 \\
\hline 1370613_s_at & Ugtla5 & $\begin{array}{l}\text { UDP glucuronosyltransferase } 1 \text { family, } \\
\text { polypeptide A5 }\end{array}$ & 0.004 & 1.51 & 71 \\
\hline 1371076_at & Cyp $2 b 2$ & $\begin{array}{l}\text { cytochrome } \mathrm{P} 450 \text {, family } 2 \text {, subfamily } \\
\text { b, polypeptide } 2\end{array}$ & 0.049 & 1.90 & 100 \\
\hline 1387093_at & Slcola2 & $\begin{array}{l}\text { solute carrier organic anion transporter } \\
\text { family, member } 1 \mathrm{~A} 2\end{array}$ & 0.044 & 1.53 & 102 \\
\hline 1371076_at & Cyp2b1 & $\begin{array}{l}\text { cytochrome } 4450 \text {, family } 2 \text {, subfamily } \\
\text { b, polypeptide } 1\end{array}$ & 0.049 & 1.90 & 141 \\
\hline 1370698_at & $U g t 2 b 1$ & $\begin{array}{l}\text { UDP glucuronosyltransferase } 2 \text { family, } \\
\text { polypeptide B1 }\end{array}$ & 0.035 & 1.60 & 150 \\
\hline 1387022_at & Aldhlal & $\begin{array}{l}\text { aldehyde dehydrogenase } 1 \text { family, } \\
\text { member A } 1\end{array}$ & 0.016 & 2.08 & 152 \\
\hline 1368797_at & Nrli3 & $\begin{array}{l}\text { nuclear receptor subfamily } 1 \text {, group I, } \\
\text { member } 3\end{array}$ & 0.043 & 2.06 & 335 \\
\hline
\end{tabular}

DEX alone and DEX plus 8-Br-cAMP co-treatment for $48 \mathrm{hr}$ in BRL 3A cells (Figure 7). Specifically, Nrli2 was up-regulated 2 times with DEX alone treatment and 4 times with DEX plus 8-Br-cAMP co-treatment. RU486 reversed the effect of DEX. However Cyp17al and Cyp2b1/2 appeared down-regulated. The $\alpha$-adrenergic receptor agonists DEXT and PE enhanced Cyp3a18 expression moderately, but the difference was not 


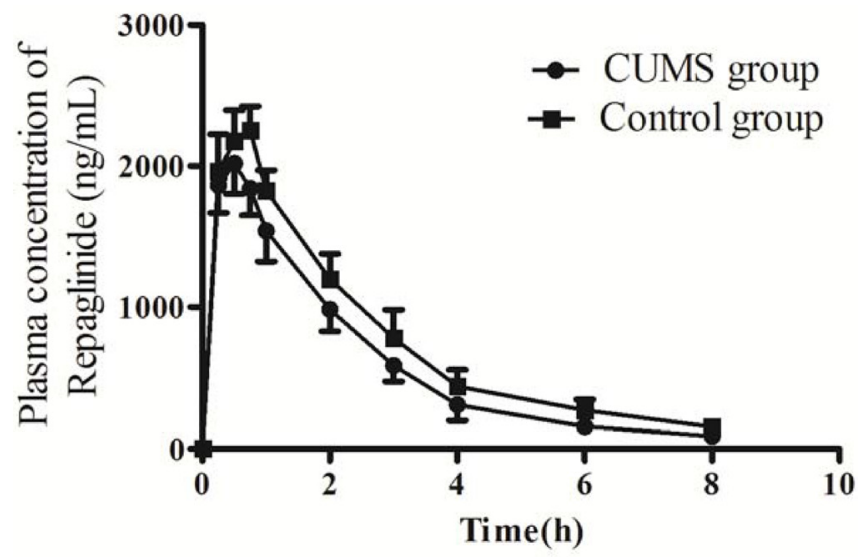

Figure 2: The plasma concentration-time curves of repaglinide in GK rats. The data were presented as mean \pm SD $(n=10)$.
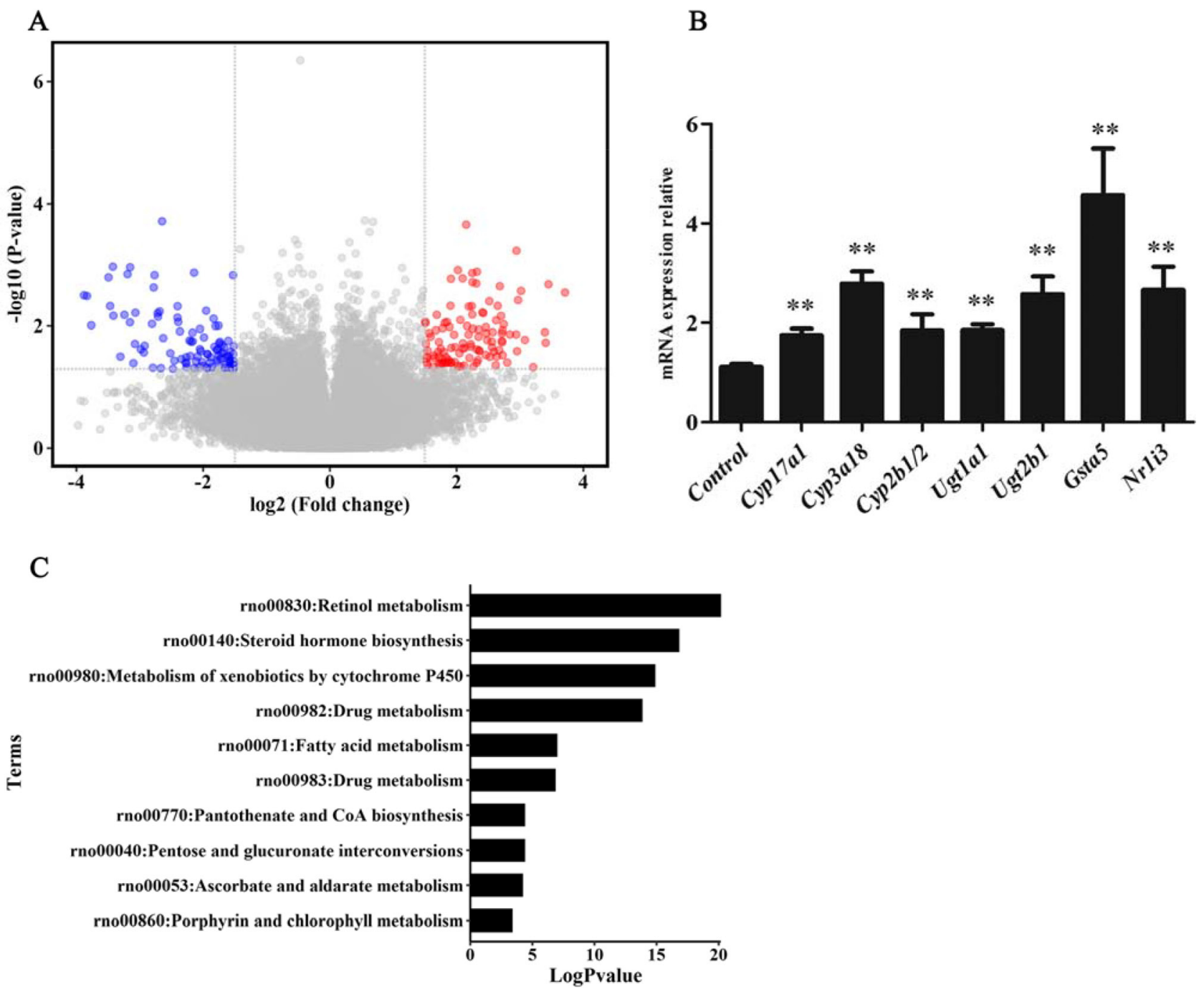

Figure 3: mRNA expression levels and KEGG pathway analyses. (A) The volcano plot image showed the mRNA expression levels of microarray in CUMS group compared with control. Black dots: equally expressed mRNAs between CUMS group compared and control $(0.5 \leq$ Fold Change $\leq 1.5)$; red dots: mRNAs were overexpressed in CUMS group compared with control $(P$-values $<0.05$, Fold Change $\geq 1.5$ ); blue dots: mRNAs in CUMS group were down-expressed compared to control $(P$-values $<0.05$, Fold Change $\leq 0.5)$. Fold changes of these mRNAs in CUMS group compared with control are shown as mean \pm SD. (B) Relative expression of differentially expressed genes(DEGs) using qRT-PCR confirmation(normalized to controls). Data are presented as the mean $\pm \mathrm{SD}, n=6, * * p<0.01$, compared with control. (C) KEGG pathway enrichment analysis of the up-regulated DEGs. 
Table 3: KEGG pathway enrichment analysis of the up-regulated DEGs

\begin{tabular}{|c|c|c|c|c|c|}
\hline KEGG ID & KEGG term & Count & Log $P$ value & FDR & Genes \\
\hline rno00830 & Retinol metabolism & 5 & $2.02 \mathrm{E}+01$ & 7.31E-04 & $\begin{array}{l}\text { Ugt1al, Aldh1a1, Cyp2b1/2, } \\
\text { Cyp3a18, Ugt2b1 }\end{array}$ \\
\hline rno00140 & Steroid hormone biosynthesis & 5 & $1.68 \mathrm{E}+01$ & 0.007 & $\begin{array}{l}\text { Ugt1a1, Cyp3a18, Cyp17a1, } \\
\text { Ugt2b1, Sult2a2 }\end{array}$ \\
\hline rno00980 & $\begin{array}{l}\text { Metabolism of xenobiotics by cytochrome } \\
\text { P450 }\end{array}$ & 5 & $1.49 \mathrm{E}+01$ & 0.028 & $\begin{array}{l}\text { Gsta5, Ugtla1, Cyp2b1/2, } \\
\text { Cyp3a18, Ugt2b1 }\end{array}$ \\
\hline rno00982 & Drug metabolism & 5 & $1.39 \mathrm{E}+01$ & 0.058 & $\begin{array}{l}\text { Gsta5, Ugt1a1, Cyp2b1, } \\
\text { Cyp3a18, Ugt2b1 }\end{array}$ \\
\hline rno00071 & Fatty acid metabolism & 2 & $7.00 \mathrm{E}+00$ & 6.517 & Ehhadh, Ecil \\
\hline rno00983 & Drug metabolism & 3 & $6.87 \mathrm{E}+00$ & 7.113 & Ugt1a1, Сур $3 a 18$, Ugt2b1 \\
\hline rno00770 & Pantothenate and CoA biosynthesis & 2 & $4.40 \mathrm{E}+00$ & 34.041 & Vnn1, Pank3 \\
\hline rno00040 & Pentose and glucuronate interconversions & 2 & $4.40 \mathrm{E}+00$ & 34.041 & Ugt1a1, Ugt2b1 \\
\hline rno00053 & Ascorbate and aldarate metabolism & 2 & $4.23 \mathrm{E}+00$ & 37.606 & Ugt1al, Ugt2b1 \\
\hline rno00860 & Porphyrin and chlorophyll metabolism & 2 & $3.39 \mathrm{E}+00$ & 57.737 & Ugt1a1, Ugt $2 b 1$ \\
\hline
\end{tabular}

KEGG, Kyoto Encyclopedia of Genes and Genomes; FDR, false discovery rate; DEGs, differentially expressed genes.

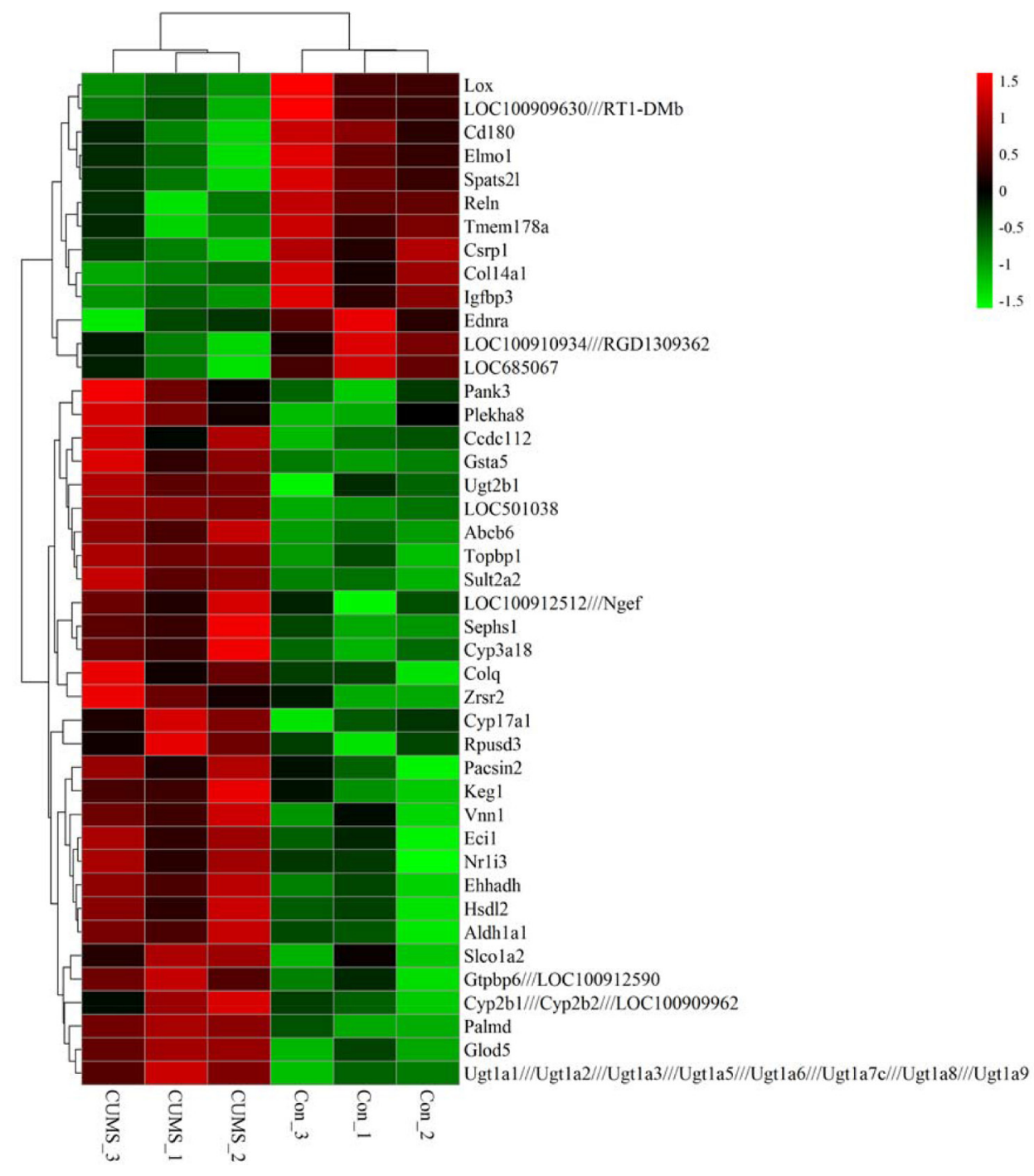

Figure 4: Hierarchical clustering heat map of differentially expressed genes in liver tissue of GK rats between CUMS and control group. Up-regulation was indicated by red, down-regulation by green. Clusters of genes showing similarity of the expression patterns were identified based on Euclidian distances. 
significant. In addition, $\beta$-receptor agonists ISO had little effect on Cyp3a18, Ugtla1, Ugt2b1, Gsta5, Nr1i2 and Nrli3 expression (Figure 8).

\section{Alteration of drug metabolizing enzymes both in liver tissue of GK rats and in BRL $3 A$ cells}

To further investigate protein expression of the interested genes, Western blot was applied both in liver tissue of GK rats and in BRL 3A cells. As shown in Figure 9 the protein expression levels of Cyp3al was enhanced moderately, but Ugt1a1 was enhanced significantly in liver tissue of GK rats $(p<0.05)$. The CAR was increased significantly in liver tissue of GK model rats, meanwhile PXR was increased significantly with DEX plus 8-BrcAMP treatment for $48 \mathrm{hr}$ in BRL 3A cells $(p<0.05)$. Adrenergic receptor antagonists including DEXT, PE and ISO didn't alter the drug metabolizing enzymes expression.

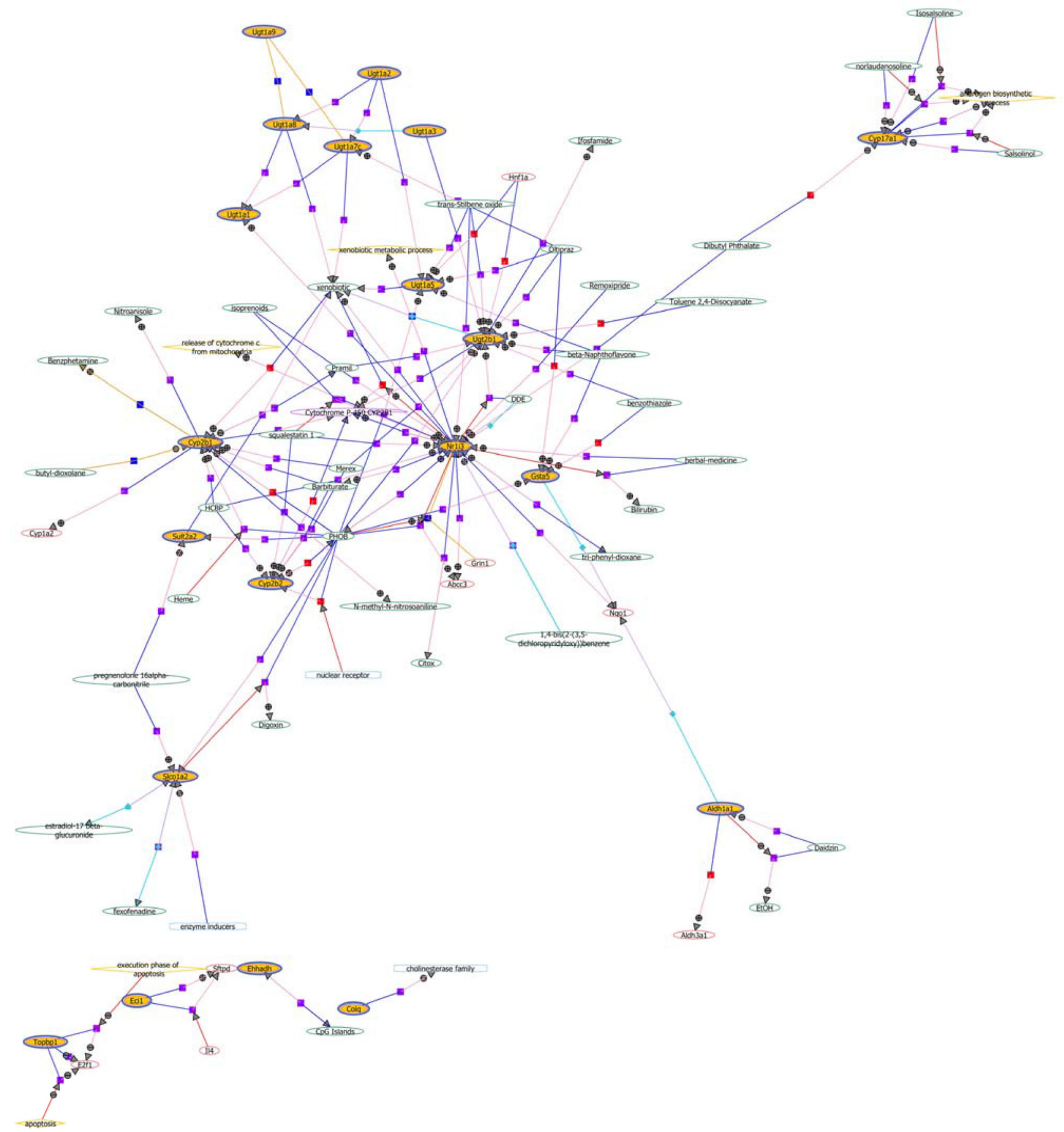

Figure 5: The network of up-regulated differentially expressed genes in liver tissue of GK rats. The yellow circle indicated the differentially expressed genes, and the arrows indicated the regulation directions. The plus sign denoted the positive regulation, while the minus sign denoted the negative regulation. 

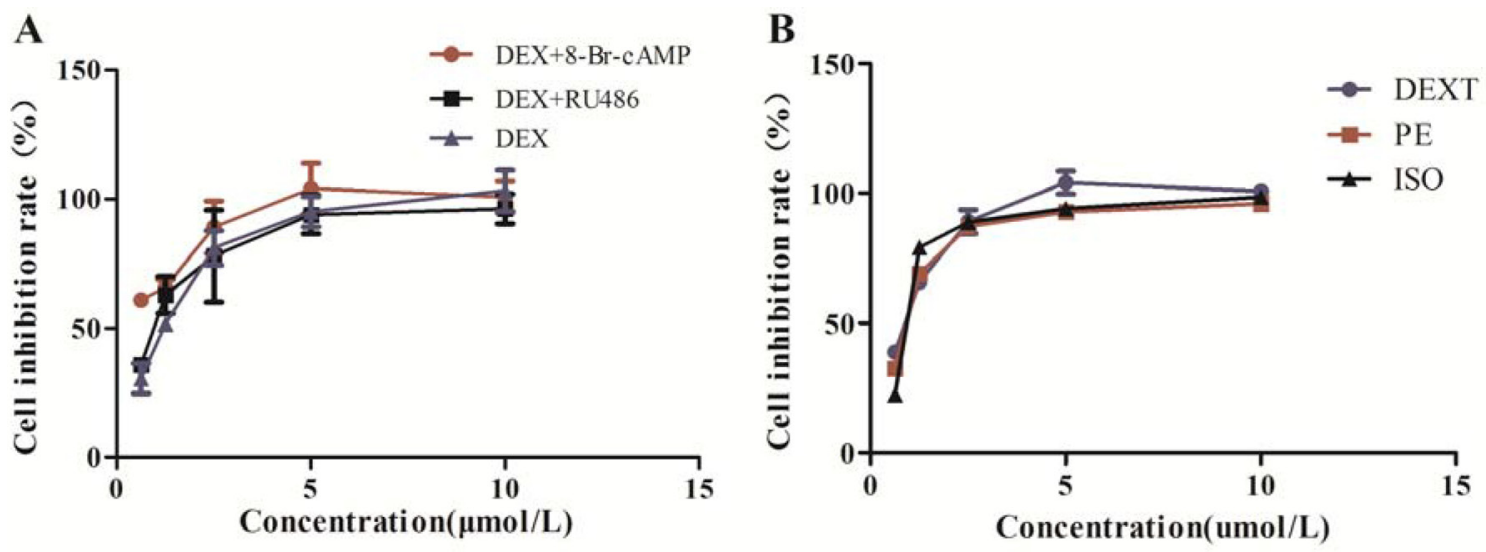

Figure 6: Cell viability. (A) DEX alone, DEX combination with 8-Br-cAMP or RU486 treated BRL 3A for 48 hr. (B) DEXT, PE and ISO treated BRL $3 \mathrm{~A}$ for $48 \mathrm{hr}$. Data were presented as the mean $\pm \mathrm{SD}$ (normalized to controls), $n=6,{ }^{*} p<0.05 v \mathrm{~s}$ control.
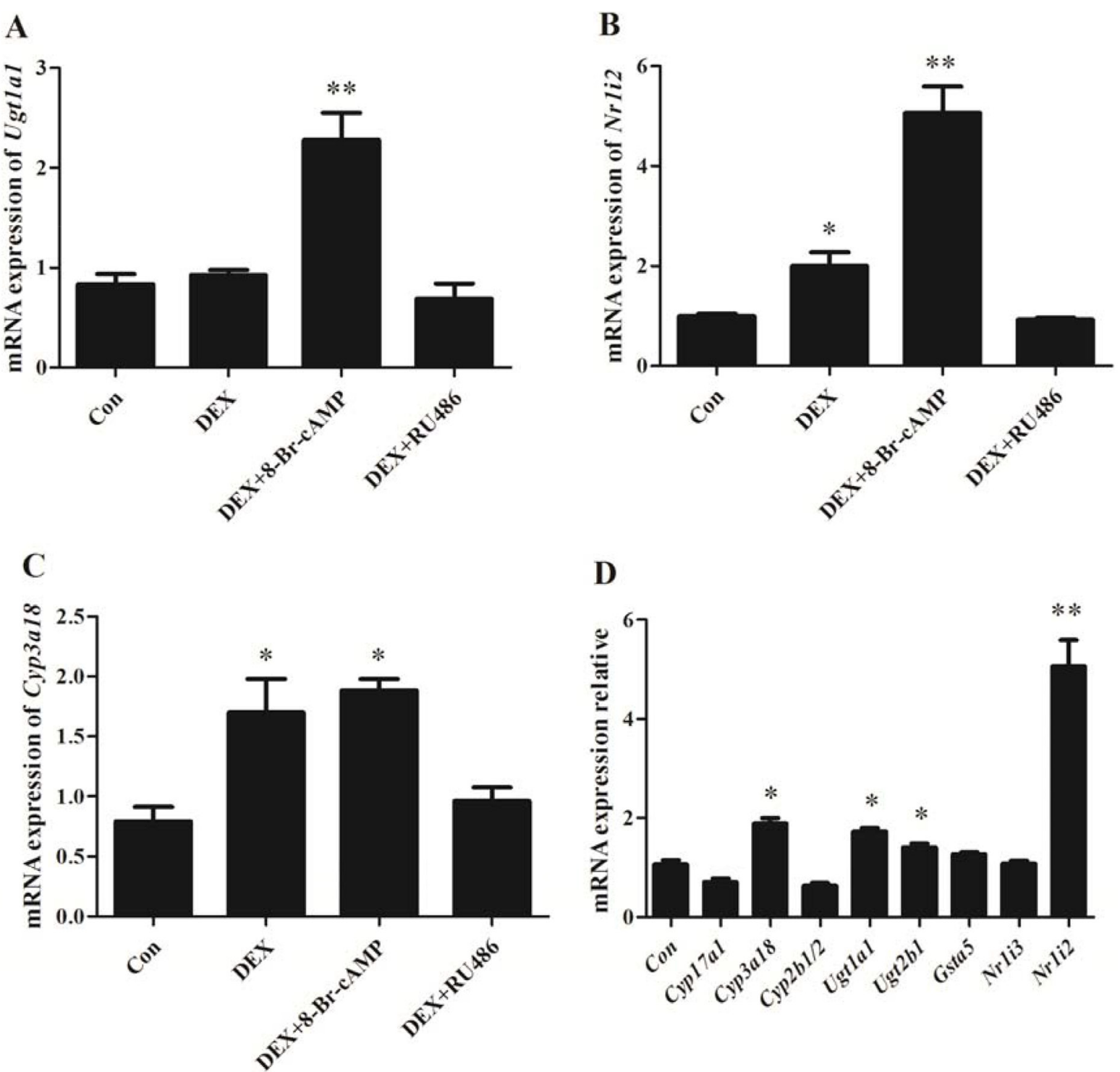

Figure 7: The mRNA expression in BRL 3A cells with DEX, RU486, 8-Br-cAMP treatment for 48 hr. (A) Ugtlal; (B) NrIi2; (C) Cyp3a18; (D) Differentially expressed genes relevant to drug-metabolism and steroid hormone biosynthesis. Data are presented as the mean $\pm \mathrm{SD}$ of the relative mRNA level (normalized to controls), $n=3,{ }^{*} p<0.05,{ }^{* *} p<0.01$ vs control. 


\section{DISCUSSION}

Various physiological and pathological factors such as age, sex, and individual genetic background can affect drug metabolism. Recently evidences showed that psychological factors also influence the drug metabolism process [16-19]. We herein established the CUMS induced-depression model with GK rats. We noted that

A

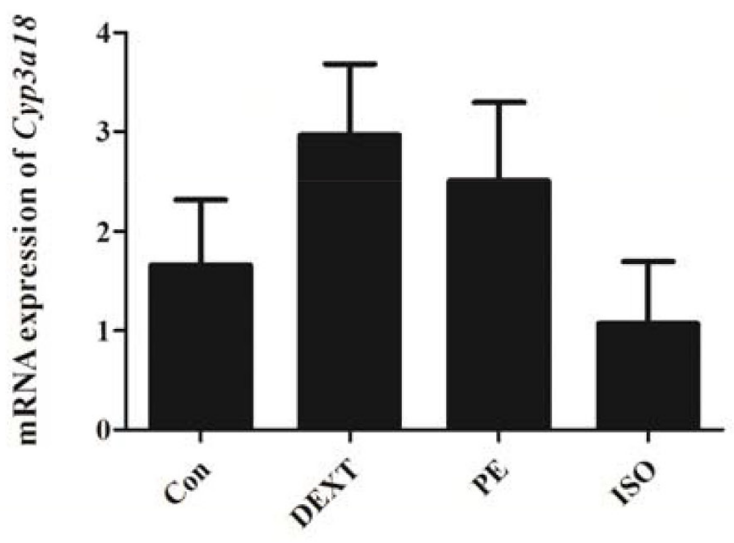

C

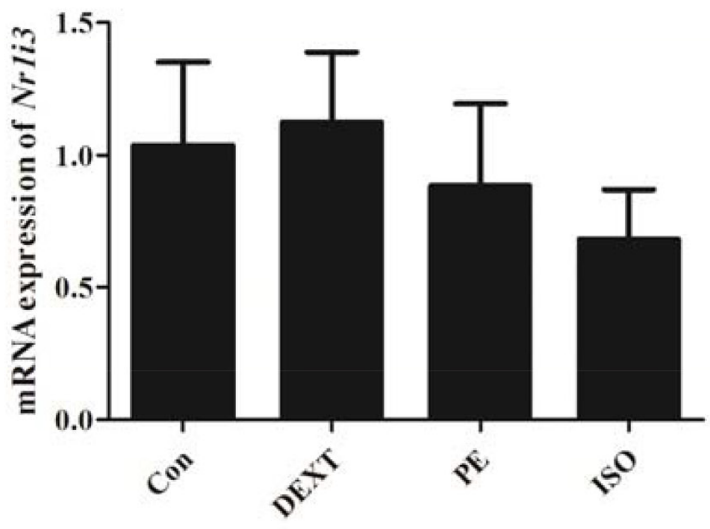

E

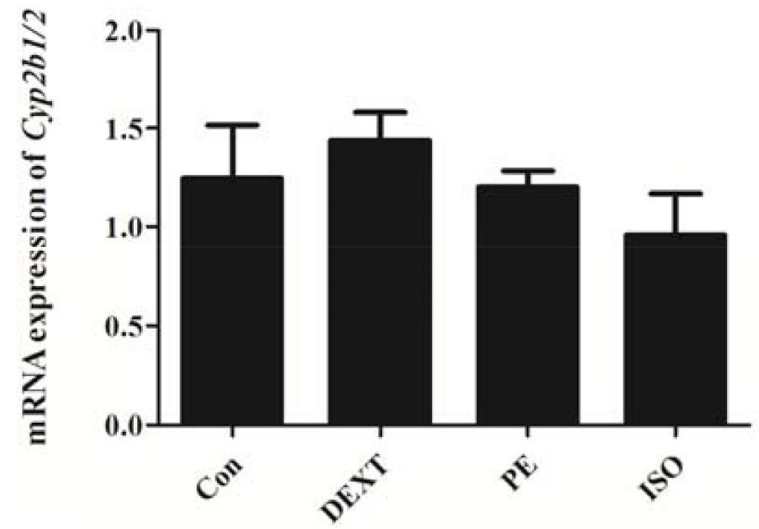

stress hormone cortisol level increased significantly and repaglinide pharmacokinetics changed in model rats. Leblond et al. found that stress hormone might regulate the expression of CYP2C11, CYP 3A1/2 in rats with chronic renal failure [20]. Therefore we surmised that pharmacokinetic change in depression model rats might be consequence of DMEs expression alters associated with hormone stress.

B

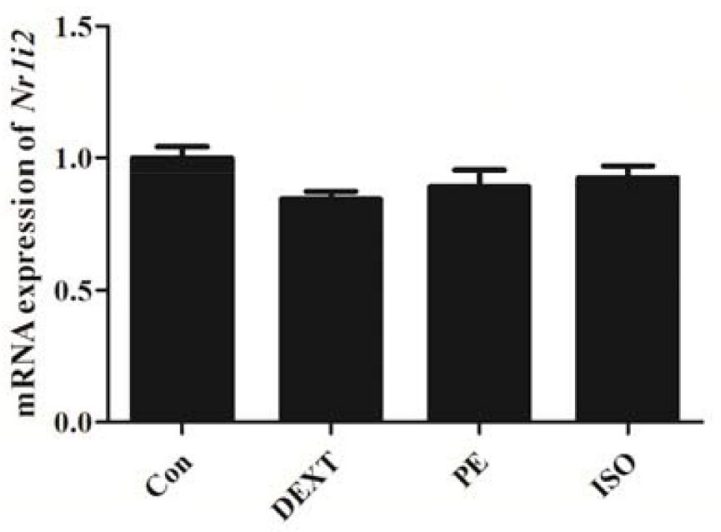

D

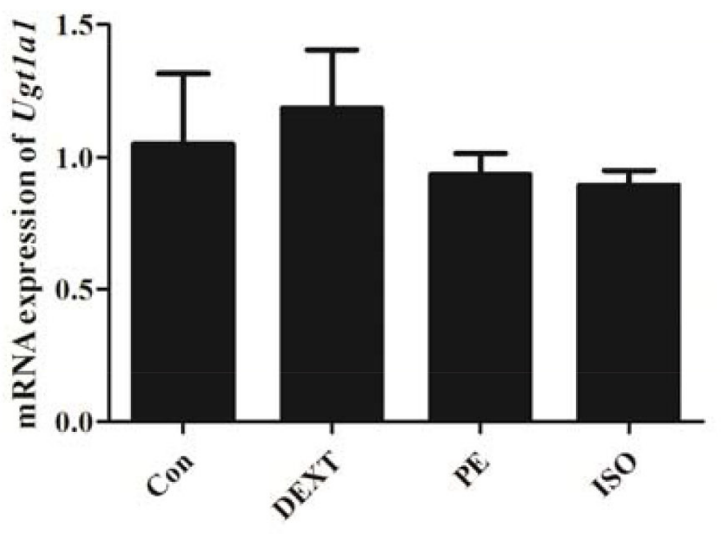

$\mathbf{F}$

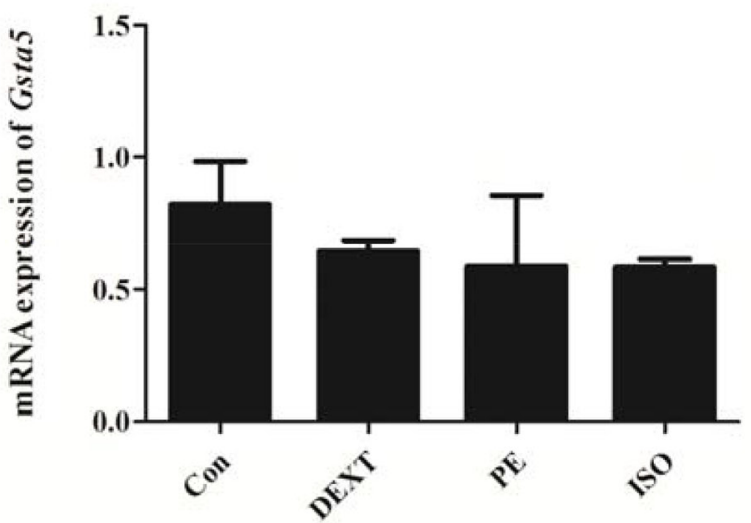

Figure 8: The mRNA expression in BRL 3A cells with DEXT, PE and ISO treatment for 48 hr. (A) Cyp3a18; (B) Nrli2; (C)Nr133; (D) Ugt1al; (E) Cyp2b1/2; (F) Gsta5. Data are presented as the mean $\pm \mathrm{SD}$ of the relative mRNA level (normalized to controls), $n=3$. 
In order to explore the underlying mechanism, we compared the gene expression profiles of liver tissue of depression model rats to that of control rats. The results indicated that mRNA expression of Cyp17a1, Cyp3a18, Cyp2b1/2, Gsta5, Ugt1a1 and Ugt2b1 were up-regulated significantly in model group rats. These differentially expressed genes (DEGs) that met the thresholds yielded and enriched in KEGG pathways of drug metabolismenzymes and steroid hormone biosynthesis. $\mathrm{Nr}$ li3 was the central node of up-regulated DEGs Using GeneSpring software analysis, which influenced the most of other genes expression. The mRNA expression of Cyp17a1, Cyp3a18, Cyp2b1/2, Gsta5, Ugt1al, Ugt2b1 and Nr1i3 in gene chip was confirmed by qRT-PCR. At same time the protein expression of Cyp3a1, Cyp2b1/2, and Ugt2b were increased slightly in model rats compared with control rats, but Ugtla1 and CAR were up-regulated significantly.

The biosynthesis of cortisol is dependent on the activity of microsomal CYP17 $\alpha$-hydroxylase/17,20-lyase [21] meanwhile steroid hormone enhances the CYP450 expression under stress [22]. In this study Cyp17al mRNA expression was up-regulated significantly in liver tissue of model rats, and cortisol was in increased in model rats, demonstrated the delicate interaction among drugmetabolism enzymes expression, stress hormone and stress in model rats. UDP-glucuronosyl transferases (UGTs) are major phase II enzyme family in the liver micro some [23]. Among them Ugtlal detoxifies bilirubin neurotoxicity by conjugating with glucuronic acid, therefore plays a critical role in the detoxification and excretion of endogenous and
A

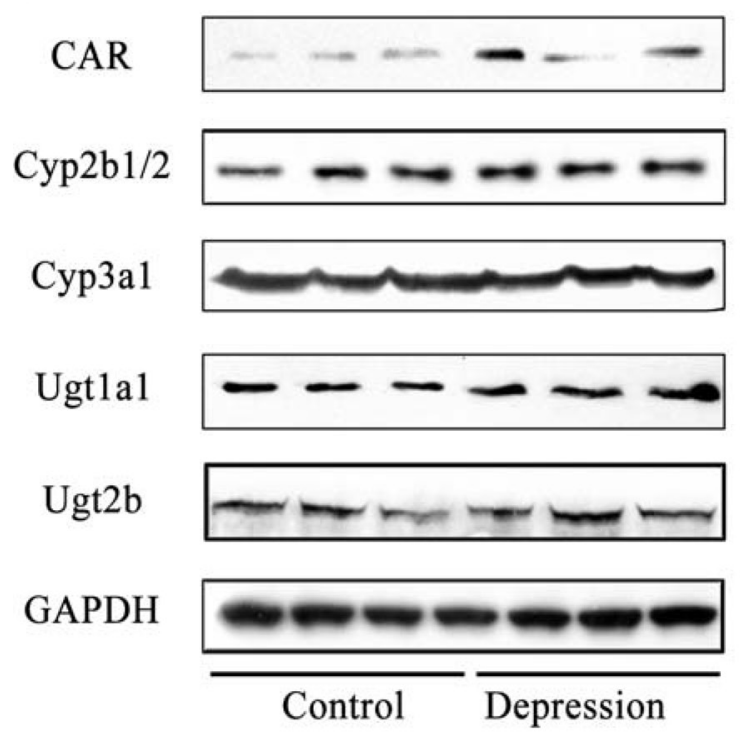

B

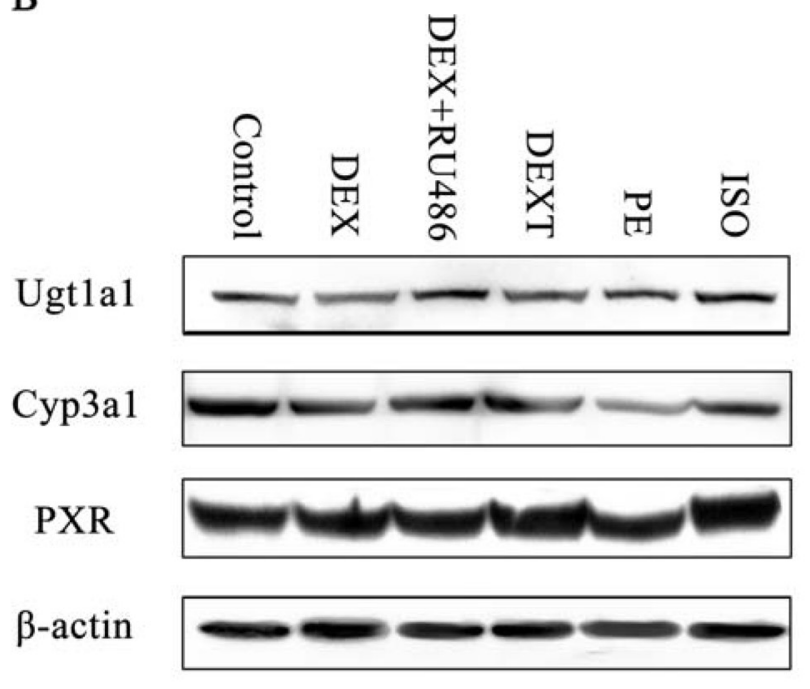

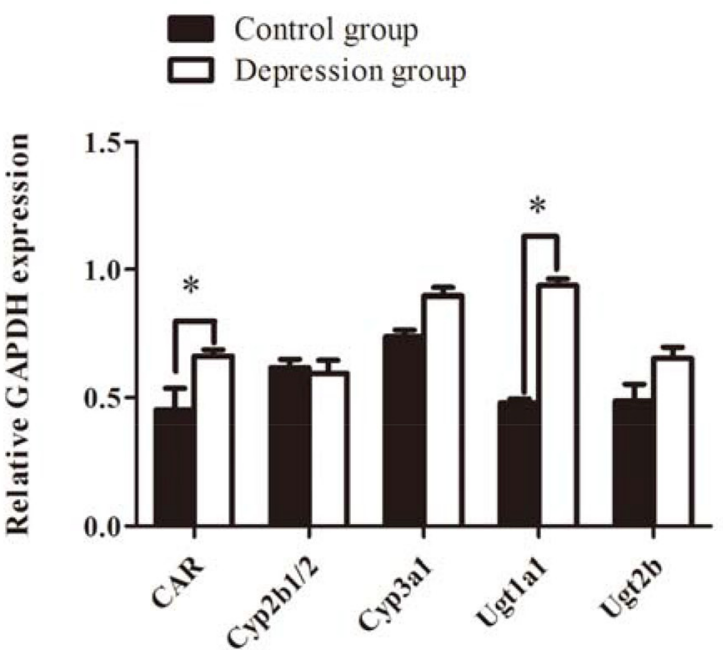

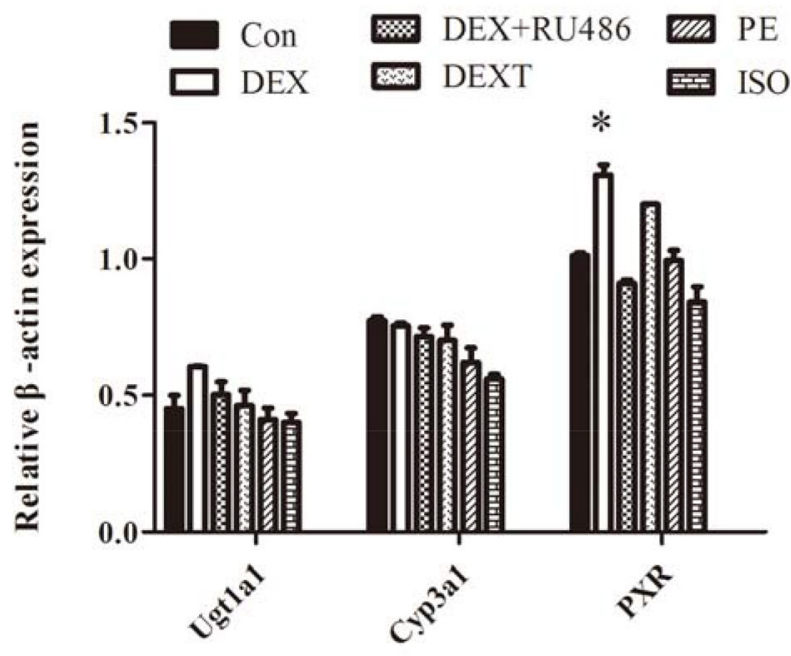

Figure 9: The protein expression of drug metabolizing enzymes. (A) The protein expression of CAR, Cyp2b1/2, Cyp3a1, Ugt1a1, Ugt2b in GK rats' liver. (B) The protein expression of Ugt1a1, Cyp3a1, PXR in BRL 3A. Data are presented as the mean \pm SD of the relative protein (normalized to controls), $n=3,{ }^{*} p<0.05$ vs control. 
exogenous lipophilic compounds [24]. Species and tissue/ cell-dependent regulation of UGT expression by ligandactivated transcription factors is often involved in the regulation of homeostasis [25]. Ugtla1 expression was up-regulated significantly in this study, suggested that Ugtlal participate in substrates metabolism to cope with stress. The transcription factor Nrli3, encoding orphan nuclear receptor CAR, regulates gene encoding DMEs and transporters in livers of rats [26]. Both mRNA expression of Nrli3 and protein expression of CAR were consistently up-regulated in depression model rats in this study. Besides GeneSpring analysis results indicated Nrli3 regulates Ugtlal and other DMEs expression.

In liver tissue of model rats KEGG pathway analysis highlighted significant enrichment in drug metabolismenzymes and steroid hormone biosynthesis pathway. To further study the role of steroid hormone in regulating the differential expression of DMEs induced by stress, rat liver cell line of BRL $3 \mathrm{~A}$ was treated with DEX. We noted that it was Nrli2 (rather than Nrli3) that increased twice as treated with DEX for $48 \mathrm{hr}$, while glucocorticoid receptor antagonist RU486 reversed this stimulatory effect. When BRL 3A cells were co-treated with DEX and 8-Br-cAMP(analog of cAMP) for $48 \mathrm{hr}$, both Ugtlal and $\mathrm{Nrli2}$ were up-regulated significantly ( $\mathrm{Nr} 1 \mathrm{i} 2$ was up-regulated almost 4 folds), along with Nrli2 encoding PXR was up-regulated. Since both glucocorticoids and cAMP stimulates corticotropin releasing hormone (CRH) promoter through the cAMP response element (CRE) [21], the synergistic stimulatory effect of DEX and 8-Br-cAMP on Ugtlal and Nrli2 might be mediated through the CRE. Over the past two decades, differential expression of DMEs induced by stress rose as an important pharmacology hot issue. Coordinated regulation of DMEs and transporters are mediated by a number of transcription factors [27] including CAR and PXR [28]. The transcriptional pathways that are activated in response to stress via CAR and PXR may be better explained the Ugtlal expression in this study.

Although epinephrine plasma level increased significantly in depression model rats, it seems that epinephrine has little-to-no effect on DMEs expression in vitro experiment. As BRL3A cells were treated with the selective adrenergic agonists DEXT and PE for $48 \mathrm{hr}$, Cyp3a18 expression was only moderately up-regulated without any significant difference. Similarly Cyp2b1/2, Ugt1a1, Gsta5, Nr1i2 and Nrli3 expression also changed a little. The protein expression of Ugt1a1, Cyp3a1 and PXR were broadly unchanged, too. Besides, $\beta$-adrenergic agonist ISO had no effect on the drug metabolism-related gene/protein expression. The mechanism of the little-tono effect of adrenergic receptor agonist in vitro assay is not clear. Adrenergic receptors are expressed in the central nervous system and peripheral nervous system involving in the regulation of various physiological functions [29, 30]. Glucocorticoids are the major regulators of CYP450, and their release are affected by the adrenergic signaling pathway [31]. Stress might directly promote the expression of CYP3A, CYP2C and CYP2D via the adrenergic pathway, or indirectly regulate the expression of CYP450 through insulin pathway [32]. The in vitro little-to-no effect of adrenergic receptor agonists in BRL 3A cells suggested that adrenergic pathway might be dominantly related with the release of glucocorticoids in vivo.

Our data suggested that CUMS-induced depression might up-regulate DMEs expression via glucocorticoid signaling pathway, and accelerate the fate of the repaglinide in spontaneous diabetes rats. Nuclear transcription factor Nrli3 and Nrli2 were specific in regulating DMEs genes under stress via glucocorticoid hormone.

\section{MATERIALS AND METHODS}

\section{Materials}

TRIzol Reagent was from Life Technologies (Carlsbad, CA, USA). RNeasy micro kit and RNase-Free DNase Set were bought from QIAGEN (GmBH, Germany). Gene Chip 3'IVT Express Kit, GeneChip ${ }^{\circledR}$ Hybridization, Wash and Stain Kit were from Affymetrix (Santa Clara, CA, USA). Dulbecco minimum essential medium (DMEM), phosphate buffer saline (PBS), fetal bovine serum (FBS), penicillin-streptomycin solution, and sodium dodecyl sulfate (SDS) were obtained from Gibco (Life Technologies, USA). Rat cortisol (CORT) and epinephrine (NE) ELISA Kit were purchased from CUSABIO (CUSABIO, USA). The RNA Extraction Kit (Code No.RR036A), PrimeScript TM RT Master Mix (Code No.RR047A), SYBR Premix Ex Taq TM (Code No.RR420A) were purchased from TaKaRa Bio Inc (Dalian, China ). The repaglinide, nateglinide, dexamethasone(DEX), 8-BrcAMP, RU486, dexmedetomidine (DEXT), phenylephrine (PE), isoprenaline (ISO), dimethyl sulphoxide (DMSO) were purchased from Sigma (St. Louis, MO, USA), The Cyp3a1, Cyp2b1/2, Ugt1a1, Ugt2b, CAR, PXR, GAPDH, $\beta$-actin primary antibody and the horseradish peroxidase conjugated goat anti-rabbit antibody were bought from Abcam (CA, USA), Pierce ECL Western Blotting Substrate from Thermo Scientific (CA, USA). Nuclear extracts (RIPA), BCA Protein Assay Kit, $5 \times$ loading buffer, Prestained Protein Molecular Weight Marker were bought from Beyotime Biotech Reagents (Shanghai, China ). The Pure Nitrocellulose (NC) Blotting Membrane was bought from Bio-Rad Laboratories (Hercules, CA, USA). All other chemicals were of analytical grade and purchased from Shanghai Biotech (Shanghai, China).

\section{Establishment of CUMS-induced depression model}

Five weeks old male GK rats were purchased from Shanghai SLAC Laboratory Animal Co., Ltd. (Animal Quality Certificate: 2007000562918), were kept in 
the Laboratory of Animal Center, East China Normal University, Shanghai (Animal Experiment License: SYXK 2010-0094). Rats were kept in the cage for 7 weeks in an SPF-grade lab until the emergence of diabetes (with blood glucose level $\geq 11 \mathrm{mmol} / \mathrm{L}$ ). Then the diabetic rats were randomly divided into two groups: control group and depression model group ( $n=10$ per group). The depression model group rat was fed alone in a cage for 8 weeks with food and water ad libitum. Each rat was given one kind of stresses daily. The stresses included activity restriction (in bottle, $1 \mathrm{hr}$ ), hot water swimming $\left(45^{\circ} \mathrm{C}, 5\right.$ $\mathrm{min})$, cold water swimming $\left(4^{\circ} \mathrm{C}, 5 \mathrm{~min}\right)$, clip tail $(1 \mathrm{~min})$, cages tilting $\left(45^{\circ} \mathrm{C}, 24 \mathrm{hr}\right)$, cage horizontal shaking $(10$ min), damp padding (24 hr), noise interference (10 min), and day/night inversion (24 hr). Each stress was used 5-6 times randomly but not consecutively to avoid rat's prediction. The control group rats were normally fed for 8 weeks with food and water ad libitum without any stress.

The open-field test was performed in a quiet room using a ZS-ZFT Video Analysis system before and after model establishment (ZSDC Sci-Tech Co, China). Each rat was individually placed in an opaque box $(100 \mathrm{~cm} \times 100$ $\mathrm{cm} \times 40 \mathrm{~cm})$ and the bottom was divided into $25 \times 25 \mathrm{~cm}^{2}$ equal-size squares. Rearing times and four claws climbing square numbers were considered as an index of vertical and horizontal scores, respectively. The behavior of each rat was video-recorded for $5 \mathrm{~min}$ [17].

Sucrose preference test was also carried out before and after model establishment. Firstly, rats were trained to adapt to $1 \%$ sucrose solution for $24 \mathrm{hr}$. Then, two bottles, one containing $1 \%$ sucrose solution and other containing tap water, were placed to each rat for $24 \mathrm{hr}$. After the adaptation, rats were deprived of water and food for $24 \mathrm{hr}$. The rats then were free to access to two bottles containing $1 \%$ sucrose solution and tap water. After $1 \mathrm{hr}$, sucrose solution and tap water consumptions were measured, and the sucrose preference was calculated by the equation as follow: sucrose preference = sucrose consumption/ (sucrose consumption + water consumption) $\times 100 \%[33]$.

Before and after the model establishment, blood samples were collected from rats' eye canthus and centrifuged to obtain plasma at $3,000 \times \mathrm{g}$ for $5 \mathrm{~min}$. The plasma cortisol (CORT) and epinephrine (NE) levels were assayed with ELISA Kit according to the instructions.

\section{Determination of plasma repaglinide concentration}

After depression model establishment, the repaglinide suspension was given by gavage at $6.0 \mathrm{mg} / \mathrm{kg}$ to all rats. Blood samples were collected into heparinized tubes at $0,0.25,0.5,0.75,1.0,2.0,3.0,4.0,6.0,8.0 \mathrm{hr}$ after administration, and then were centrifuged at $3,000 \times \mathrm{g}$ for $5 \mathrm{~min}$ at $4^{\circ} \mathrm{C}$. The plasma samples were stored at $-80^{\circ} \mathrm{C}$ for LC-MS/MS analysis.
The plasma concentration of repaglinide was determined by LC-MS/MS based on reference with a minor modification [34]. A volume of $100 \mu \mathrm{L}$ nateglinide, as an internal standard, and $300 \mu \mathrm{L}$ methanol were mixed with $100 \mu \mathrm{L}$ plasma sample. Then mixture solution was vortex-mixed for $1 \mathrm{~min}$, followed by centrifugation at $15,000 \mathrm{rpm}$ for $5 \mathrm{~min}$. The supernatant was directly injected for LC-MS/MS analysis. The LC-MS/MS system consisted of Agilent 1260 HPLC (Agilent, USA) couple to an Agilent 6420 triple quadrupole mass spectrometer (Agilent, USA). The separation was performed on a ZORBAX EP- $\mathrm{C}_{18}$ column $(50 \mathrm{~mm} \times 2.1 \mathrm{~mm}, 1.8 \mu \mathrm{m}$, Agilent) at $35^{\circ} \mathrm{C}$ with methanol $-0.1 \%$ formic acid aqueous solution (80:20) as a mobile phase at a flow rate of $1.0 \mathrm{ml} / \mathrm{min}$. The mass spectrometer was run in operated positive electrospray ionization (ESI) mode, with the electrospray voltage, gas pressure and temperature set to $4,000 \mathrm{~V}, 15 \mathrm{psi}$ and $350^{\circ} \mathrm{C}$, respectively, which was set to monitor the $\mathrm{m} / \mathrm{z} 453.2 \rightarrow \mathrm{m} / \mathrm{z} 230.1$ for repaglinide and $\mathrm{m} / \mathrm{z} 316.0 \rightarrow \mathrm{m} / \mathrm{z} 168.1$ for nateglinide, respectively. The HPLC system and mass spectrometer were controlled by Masshunter Workstation software (version B.06.00, Agilent, USA), and data were collected with the same software. Pharmacokinetic parameters were calculated by PKSolver 2.0, which is an add-in program for pharmacokinetic data analysis in Microsoft Excel [35].

\section{Gene expression profiling and bioinformatics analysis}

GK rats were sacrificed after the pharmacokinetic experiment was finished. Rats' livers were collected, washed with $0.9 \% \mathrm{NaCl}$ solution, and stored at $-80^{\circ} \mathrm{C}$ until use. Total RNA was extracted using TRIzol Reagent following the instructions. RIN number was used to inspect RNA integrity by an Agilent Bioanalyzer 2100 (Agilent technologies, Santa Clara, CA, US). Qualified total RNA was further purified by RNeasy micro kit and RNase-Free DNase Set. Total RNA were amplified, labelled and purified by using Gene Chip 3'IVT Express Kit followed the manufacturer's instructions to obtain biotin labelled cRNA.

Array hybridization and wash was performed using GeneChip ${ }^{\circledR}$ Hybridization, Wash and Stain Kit in Hybridization Oven 645 (Affymetrix, Santa Clara, CA, USA) and Fluidics Station 450 (Affymetrix, Santa Clara, CA, USA) followed the instructions. Slides were scanned by GeneChip ${ }^{\circledR}$ Scanner 3000 (Affymetrix, Santa Clara, CA, USA) and Command Console Software 3.1 (Affymetrix, Santa Clara, CA, USA) with default settings. Microarray quality control assessment and data acquisition were performed with the GeneChip ${ }^{\circledR}$ Operating Software (GCOS, Affymetrix). Raw data which could be available from the databases (GSE94988) were normalized by MAS 5.0 algorithm, and the differentially expressed genes (DEGs) were further analyzed. The intention DEGs 
Table 4: Primer sequence for quantitative real-time polymerase chain reaction

\begin{tabular}{|c|c|c|c|}
\hline Gene symbol & GeneBank accession No. & Primer sequence $\left(5^{\prime} \rightarrow 3^{\prime}\right)$ & Amplicon size (bp) \\
\hline \multirow[t]{2}{*}{ Cyp17a1 } & NM_012753.2 & Forward: TCTGTGCTATCTGCTTCAACATCTC & 88 \\
\hline & & Reverse: GCATCCACGATACCCTCAGTAAA & \\
\hline \multirow[t]{2}{*}{ Сур $3 a 18$} & NM_145782 & Forward: ACAATCCTGTCTCCAACCTTCAC & 115 \\
\hline & & Reverse: GCTCCCCTTTTGCTTCTTCTC & \\
\hline \multirow[t]{2}{*}{ Cyp $2 b 1 / 2$} & NM_001134844 & Forward: GGGAAAGAGGAGTGTGGAAGAA & 132 \\
\hline & & Reverse: GAGCAGATGATGTTGGCTGTG & \\
\hline \multirow[t]{2}{*}{ Ugtlal } & NM_001039549 & Forward: TTGGTGGGATAAACTGCCTTCA & 165 \\
\hline & & Reverse: 5'-GAATTCTGCCCAAAGCCTCA-3' & \\
\hline \multirow[t]{2}{*}{ Ugt2bl } & NM_173295.1 & Forward: GCTTCTGCTCTTGCCCAAATTC & 176 \\
\hline & & Reverse: GCCTCATAGATGCCATTTGTTCC & \\
\hline \multirow[t]{2}{*}{ Gsta5 } & NM_001010921.1 & Forward: CATCCATGGCTGGCTTTC & 165 \\
\hline & & Reverse: CAGCCACGGATGTGCTCAA & \\
\hline \multirow[t]{2}{*}{ Nrli3 } & NM_001270838.1 & Forward: CCTACATGTTCAAGGGCGTCATC & 119 \\
\hline & & Reverse: TGTCGAACATCGTGTTGAACCTC & \\
\hline \multirow[t]{2}{*}{ Nrli2 } & NM_052980.2 & Forward: CCTACATGTTCAAGGGCGTCATC & 138 \\
\hline & & Reverse: TGTCGAACATCGTGTTGAACCTC & \\
\hline \multirow[t]{2}{*}{ GAPDH } & NM_017008.4 & Forward: TCCTGCACCACCAACTGCTTAGC & 125 \\
\hline & & Reverse: GAGGGGCCATCCACAGTCTTCTG & \\
\hline
\end{tabular}

were mapped to the KEGG pathway, and the significant pathways were calculated based on the location and expression level of the genes in the pathway. The interaction among up-regulated DEGs was explored using GeneSpring Software 11.0 (Agilent technologies, Santa Clara, CA, USA).

\section{Confirmation of mRNA expression by qRT-PCR}

Total RNA was extracted using TaKaRa MiniBEST Universal RNA Extraction Kit according to the instructions. The RNA concentration was determined using NanoDrop Spectrophotometer (Thermo Scientific, USA) at an absorbance of $260 \mathrm{~nm}$. For quantitative RTPCR analysis, total RNA was transcribed to cDNA using PrimeScript RT reagent Kit with gDNA Eraser. Real-time PCR was performed with ABI7500 Real-time PCR system using SYBR green quantitative PCR master mix. To normalize the mRNA expression, the housekeeping gene glyceraldehyde-3-phosphate dehydrogenase (GAPDH) was used as an external standard. The primer sequences were shown in Table 4. The relative amount of each mRNA was calculated using the $2^{-\Delta \Delta \mathrm{Ct}}$ formula [36].

\section{Cell tests}

Rat liver cell line of BRL 3A was purchased from the cell bank, Chinese Academy of Science. The cells were cultured in DMEM supplemented with $10 \%$ FBS in a humidified incubator with $5 \% \mathrm{CO}_{2}$ and $95 \%$ air at $37^{\circ} \mathrm{C}$.
After subconfluence, the cells were seeded into either 96-well or 6-well plates at the indicated density. The culture media were replaced every 2 days.

The viability of the BRL 3A cells was quantified by using Cell Counting Kit (CCK) assay. Cells were seeded into 96-well plates and dose-response experiments started $24 \mathrm{hr}$ later. BRL 3A cells were treated either with DEX, or the adrenergic receptor agonists of DEXT, PE, ISO alone, at different doses ranging from $0.625-10 \mu \mathrm{mol} / \mathrm{L}$ and DEX in combination with the glucocorticoid receptors antagonist of the Mifepristone (RU486) or 8-Br-cAMP (cAMP analogue) for $48 \mathrm{hr}$. Then $10 \mathrm{uL}$ $\mathrm{CCK}$ was added to each well and incubated at $37^{\circ} \mathrm{C}$ for $2 \mathrm{hr}$. At last, optical densities (ODs) were measured by the spectrometric absorbance at $450 \mathrm{~nm}$ on a microplate reader (Bio-Rad Laboratories, CA, USA). Results were plotted as percent of survival and concentration-response curves were fitted in order to determine no inhibition of cell growth value. Nontoxic drug concentration for each drug was determined. Cells were seeded into 6-wells plates and treated with DEX or the adrenergic receptor agonists alone, or DEX co-treated with 8-Br-cAMP, RU486 for $48 \mathrm{hr}$. Cells were collected for mRNA and proteins expression measurement as the liver tissue.

\section{Western blot assay}

Protein was extracted using Beyotime Biotech Reagents (Shanghai, China). The concentrations were determined with a BCA protein assay kit. The protein 
sample $(40 \mu \mathrm{g})$ was loaded on $10 \%$ Bis-Tris Gel which was then transferred to NC membranes for $60 \mathrm{~min}$ at $2.5 \mathrm{~mA}$ / $\mathrm{cm}^{2}$ at room temperature using a Semi-Dry blotting system (Millipore Co., Chicago, IL). Membranes were blocked with $5 \%$ none fat milk in TBS $/ 0.05 \%$ tween (TBST) for $2 \mathrm{hr}$ at room temperature, washed 3 times for $10 \mathrm{~min}$ in TBST, and then incubated with the primary antibodies against CAR(1:500), PXR(1:1000), Cyp3a1(1:1000), Cyp2b1/2(1:1000), Ugt1a1(1:1000), Ugt2b(1:1000), GAPDH and $\beta$-actin (1:1000) diluted in TBST respectively over night at $4^{\circ} \mathrm{C}$. Anti-rabbit (diluted 1:5000 in TBST) horseradish-peroxidase-conjugated second antibodies were applied after washing the blots 3 times in TBST for 10 minutes. Chemiluminescence signal was developed using an ECL kit according to the instructions, and the band signal was detected by the FluorChem FC3 System. Band densitometry was quantified using Quantity One Analysis software (version 4.5.2, Bio-Rad Laboratories, CA, USA) and signaling was expressed as relative values as normalized by GAPDH or $\beta$-actin bands.

\section{Statistical analysis}

For microarray data analysis, ANOVA and filtering lists by $p$-value and fold-change were performed with the GeneSpring Software. Heatmap and gene clustering analysis of the gene expression data were carried out with $\mathrm{R}$ and BioConductor packages. A statistical comparison of the CUMS-induced effects was made by hierarchical clustering. Statistical analysis of other data was performed with GraphPad Prism 5 (GraphPad Software, Inc., La Jolla, CA, USA). Student $t$-test was used to assess statistical significance between groups. Data were expressed as mean \pm standard deviation (SD). $* p<0.05$, or $* * p<0.01$ were considered statistically significant.

\section{Authors' contributions}

HyW and TZ conceived and designed the experiments, performed the experiments, collected samples and wrote the paper draft. ByT, LZ and MmL established CUMS-induced depression model. ZjX performed the pharmacokinetic study. FX conceived and designed the experiments, contributed reagents/materials/ analysis tools, and revised the paper.

\section{Ethics statement}

This study was approved by Institutional Ethical Committees of Fengxian Hospital and was performed in accordance with the principles of the Declaration of Helsinki as revised in 2000.

\section{CONFLICTS OF INTEREST}

The authors declare no competing financial interests.

\section{FUNDING}

This work was supported by National Natural Science Foundation of China (No. 81402995) and Natural Science Foundation of Shanghai (No.14ZR1434700).

\section{REFERENCES}

1. Kearns A, Whitley E, Tannahill C, Ellaway A. Loneliness, social relations and health and well-being in deprived communities. Psychology, Health \& Medicine. 2015; 20:332-344.

2. Jones A, Pruessner JC, McMillan MR, Jones RW, Kowalik GT, Steeden JA, Williams B, Taylor AM, Muthurangu V. Physiological adaptations to chronic stress in healthy humans - why might the sexes have evolved different energy utilisation strategies? J Physiol. 2016; 594:4297-4307.

3. Kinnunen-Amoroso M, Liira J. Work-related stress management by Finnish enterprises. Ind Health. 2014; 52:216-224.

4. Chaumette B, Kebir O, Mam Lam Fook C, Bourgin J, Godsil BP, Gaillard R, Jay TM, Krebs MO. [Stress and psychotic transition: A literature review]. [Article in French]. Encephale. 2016; 42:367-373.

5. Agius A, Xuereb RB, Carrick-Sen D, Sultana R, Rankin J. The co-existence of depression, anxiety and post-traumatic stress symptoms in the perinatal period: A systematic review. Midwifery. 2016; 36:70-79.

6. Puig-Perez S, Villada C, Pulopulos MM, Hidalgo V, Salvador A. How are neuroticism and depression related to the psychophysiological stress response to acute stress in healthy older people? Physiology \& behavior. 2016; 156:128-136.

7. Rodríguez-Naranjo C, Caño A. Daily stress and coping styles in adolescent hopelessness depression: Moderating effects of gender. Personality and Individual Differences. 2016; 97:109-114.

8. Franco AJ, Chen C, Scullen T, Zsombok A, Salahudeen AA, Di S, Herman JP, Tasker JG. Sensitization of the Hypothalamic-Pituitary-Adrenal Axis in a Male Rat Chronic Stress Model. Endocrinology. 2016; 157:2346-2355.

9. Wu LL, Liu Y, Yan C, Pan Y, Su JF, Wu WK. Antidepressant-Like Effects of Fractions Prepared from Danzhi-Xiaoyao-San Decoction in Rats with Chronic Unpredictable Mild Stress: Effects on HypothalamicPituitary-Adrenal Axis, Arginine Vasopressin, and Neurotransmitters. Evid Based Complement Alternat Med. 2016; 2016:6784689-6784689.

10. Daskalopoulos EP, Malliou F, Rentesi G, Marselos M, Lang MA, Konstandi M. Stress is a critical player in CYP3A, CYP2C, and CYP2D regulation: role of adrenergic receptor signaling pathways. Am J Physiol Endocrinol Metab. 2012; 303:E40-54. 
11. Konstandi M, Johnson EO, Lang MA. Consequences of psychophysiological stress on cytochrome P450catalyzed drug metabolism. Neurosci Biobehav Rev. 2014; 45:149-167.

12. van Son J, Nyklíček I, Nefs G, Speight J, Pop VJ, Pouwer F. The association between mindfulness and emotional distress in adults with diabetes: Could mindfulness serve as a buffer? Results from Diabetes MILES: The Netherlands. J Behav Med. 2014; 38:251-260.

13. Scott LJ. Repaglinide: a review of its use in type 2 diabetes mellitus. Drugs. 2012; 72:249-272.

14. Li D, Li J, Li H, Wu Q, Li QX. Antioxidant properties of repaglinide and its protections against cyclosporine A-induced renal tubular injury. Iran J Basic Med Sci. 2016; 19:749-754.

15. Du QQ, Wang ZJ, He L, Jiang XH, Wang L. PXR polymorphisms and their impact on pharmacokinetics/ pharmacodynamics of repaglinide in healthy Chinese volunteers. Eur J Clin Pharmacol. 2013; 69:1917-1925.

16. Duan JJ, Zhou T, Chen X, Wang Y, Wen YG, Xu F. Pharmacokinetics of 5-fluorouracil and cyclophosphamide in depression rats. Eur Rev Med Pharmacol Sci. 2012; $16: 427-436$.

17. Xia ZC, Wei HY, Duan JJ, Zhou T, Yang Z, Xu F. Chronic unpredicted mild stress-induced depression alter saxagliptin pharmacokinetics and CYP450 activity in GK rats. PeerJ. 2016; 4:e1611-e1611.

18. Zeng Y, Xie X, Duan J, Zhou T, Zhang Y, Yang M, Xu F. Perturbation of mitiglinide metabolism by chronic unpredicted mild stress in rats. Sci Rep. 2014; 21:3794-3794.

19. Duan J, Zeng Y, Zhou T, Zhang Y, Xu F. Study on the pharmacokinetics of tacrolimus in depression model rats. Int J Pharmacol. 2013; 9:265-270.

20. Leblond F, GuéVin C, Demers C, Pellerin I, GasconBarré M, Pichette V. Down regulation of hepatic cytochrome P450 in chronic renal failure. J Am Soc Nephrol. 2001; 12:326-332.

21. King BR, Smith R, Nicholson RC. Novel glucocorticoid and cAMP interactions on the $\mathrm{CRH}$ gene promoter. Mol Cell Endocrinol. 2002; 194:19-28.

22. Kienhuis AS, Wortelboer HM, Maas WJ, van Herwijnen M, Kleinjans JCS, van Delft JHM, Stierum RH. A sandwichcultured rat hepatocyte system with increased metabolic competence evaluated by gene expression profiling. Toxicol In Vitro. 2007; 21:892-901.

23. Bock KW. The UDP-glycosyltransferase (UGT) superfamily expressed in humans, insects and plants: Animal-plant armsrace and co-evolution. Biochem Pharmacol. 2016; 99:11-17.

24. Sugatani J. Function, Genetic Polymorphism, and Transcriptional Regulation of Human UDPglucuronosyltransferase (UGT) 1A1. Drug Metab Pharmacokinet. 2013; 28:83-92.

25. Fang ZZ, He RR, Cao YF, Tanaka N, Jiang C, Krausz KW, Qi Y, Dong PP, Ai CZ, Sun XY, Hong M,
Ge GB, Gonzalez FJ, et al. A model of in vitro UDPglucuronosyltransferase inhibition by bile acids predicts possible metabolic disorders. J Lipid Res. 2013; 54:3334-3344.

26. Sugatani J, Sueyoshi T, Negishi M, Miwa M. Regulation of the human UGT1A1 gene by nuclear receptors constitutive active/androstane receptor, pregnane $\mathrm{X}$ receptor, and glucocorticoid receptor. Methods Enzymol. 2005; 400:92-104.

27. Handschin C, Meyer UA. Induction of drug metabolism: the role of nuclear receptors. Pharmacol Rev. 2003; 55:649-673.

28. Wagner M, Halilbasic E, Marschall HU, Zollner G, Fickert P, Langner C, Zatloukal K, Denk H, Trauner M. CAR and PXR agonists stimulate hepatic bile acid and bilirubin detoxification and elimination pathways in mice. Hepatology. 2005; 42:420-430.

29. Nalepa I, Kreiner G, Bielawski A, Rafa-Zabłocka K, Roman A. $\alpha 1$-Adrenergic receptor subtypes in the central nervous system: insights from genetically engineered mouse models. Pharmacol Rep. 2013; 65:1489-1497.

30. Oshima N, Onimaru H, Yamamoto K, Takechi H, Nishida Y, Oda T, Kumagai H. Expression and functions of $\beta 1$ - and $\beta 2$ adrenergic receptors on the bulbospinal neurons in the rostral ventrolateral medulla. Hypertens Res. 2014; 37:976-983.

31. Schuetz EG, Guzelian PS. Induction of cytochrome $\mathrm{P}-450$ by glucocorticoids in rat liver. II. Evidence that glucocorticoids regulate induction of cytochrome P-450 by a nonclassical receptor mechanism. J Biol Chem. 1984; 259:2007-2012.

32. Woodcroft KJ, Novak RF. Insulin effects on CYP2E1, 2B, $3 \mathrm{~A}$, and $4 \mathrm{~A}$ expression in primary cultured rat hepatocytes. Chem Biol Interact. 1997; 107:75-91.

33. Mao QQ, Ip SP, Ko KM, Tsai SH, Che CT. Peony glycosides produce antidepressant-like action in mice exposed to chronic unpredictable mild stress: effects on hypothalamicpituitary-adrenal function and brain-derived neurotrophic factor. Prog Neuropsychopharmacol Biol Psychiatry. 2009; 33:1211-1216.

34. Ma Y, Zhou Y, Zhang G, Rao Z, Huang J, Wei Y, Wu X. [Simultaneous determination of repaglinide and pravastatin sodium in rat plasma by LC-MS/MS and its application on pharmacokinetic interactions study]. [Article in Chinese]. Yao Xue Xue Bao. 2014; 49:72-77.

35. Zhang Y, Huo M, Zhou J, Xie S. PKSolver: An add-in program for pharmacokinetic and pharmacodynamic data analysis in Microsoft Excel. Comput Methods Programs Biomed. 2010; 99:306-314.

36. Winer J, Jung CK, Shackel I, Williams PM. Development and validation of real-time quantitative reverse transcriptasepolymerase chain reaction for monitoring gene expression in cardiac myocytes in vitro. Anal Biochem. 1999; 270:41-49. 